\title{
HPPD-Inhibiting Herbicides Alone or in Tank-Mix with Atrazine in Elephant Grass
}

\author{
Alexandre M. Brighenti ${ }^{1}$, Juarez C. Machado ${ }^{1}$, Francisco J. S. Ledo ${ }^{1}$, Leonardo H. F. Calsavara ${ }^{2}$ \\ \& Yago V. Guerra Varotto ${ }^{3}$ \\ ${ }^{1}$ Embrapa Dairy Cattle, Juiz de Fora, Brazil \\ ${ }^{2}$ Emater-MG, Coronel Xavier Chaves, Brazil \\ ${ }^{3}$ Centro de Ensino Superior de Juiz de Fora, Juiz de Fora, Brazil \\ Correspondence: Alexandre M. Brighenti, Embrapa Dairy Cattle, Rua Eugênio do Nascimento, 610, Bairro Dom \\ Bosco, Juiz de Fora, MG, Brazil. Tel: 55-032-3311-7556. E-mail: alexandre.brighenti@embrapa.br
}

Received: August 21, 2017

Accepted: September 27, $2017 \quad$ Online Published: October 15, 2017

doi:10.5539/jas.v9n11p234

URL: https://doi.org/10.5539/jas.v9n11p234

\begin{abstract}
The interference imposed by weeds is one of the most important factors limiting elephant grass forage yield. Two experiments were carried out in 2015/2016 and 2017 to evaluate the selectivity and weed control of 4-hydroxyphenylpyruvate dioxygenase (HPPD)-inhibiting herbicides applied alone or in combination with atrazine in elephant grass. The treatments applied in the experiment conducted in Valença, Rio de Janeiro State, Brazil, were as follows: two rates of mesotrione $\left(0.072\right.$ and $0.144 \mathrm{~kg} \mathrm{ha}^{-1}+0.5 \% \mathrm{v} / \mathrm{v}$ mineral oil - Assist $\left.{ }^{\circledR}\right)$, two rates of tembotrione $\left(0.075\right.$ and $0.100 \mathrm{~kg} \mathrm{ha}^{-1}+0.5 \% \mathrm{v} / \mathrm{v}$ mineral oil - Aureo () , atrazine + mesotrione $(1.25+$ $0.072 \mathrm{~kg} \mathrm{ha}^{-1}+0.5 \% \mathrm{v} / \mathrm{v}$ mineral oil - Assist $\left.{ }^{\circledR}\right)$, atrazine + tembotrione $\left(1.25+0.100 \mathrm{~kg} \mathrm{ha}^{-1}+0.5 \% \mathrm{v} / \mathrm{v}\right.$ mineral oil - Aureo $\left.{ }^{\circledR}\right)$, atrazine + mesotrione $\left(1.25+0.072 \mathrm{~kg} \mathrm{ha}^{-1}\right)$, atrazine + tembotrione $\left(1.25+0.100 \mathrm{~kg} \mathrm{ha}^{-1}\right)$ and two checks (weed-free check and weedy check). The same herbicide treatments and a check without application were applied in an experiment conducted in Coronel Pacheco, Minas Gerais State, Brazil. Two application rates of mesotrione with the addition of mineral oil or the tank mixture of atrazine plus mesotrione, with or without the addition of mineral oil, did not provide injuries capable to reduce elephant grass forage yield. Tembotrione was phytotoxic to elephant grass when applied with mineral oil. Atrazine plus tembotrione in a tank-mix, with or without mineral oil, were also phytotoxic to elephant grass. All treatments provided satisfactory weed control.
\end{abstract}

Keywords: forage, Napier grass, pasture, Pennisetum purpurem, weeds

\section{Introduction}

The majority of Brazil's milk and meat production is based on the use of pasture. Thus, the search for forage species with high productivity and forage quality for cattle feeding has great importance. Elephant grass (Pennisetum purpureum Schum.) is suitable for this purpose and widely used in cattle raising, mainly for cutting, grazing and silage production (Santos et al., 2013; Maia et al., 2015). In addition to being an excellent animal feed, elephant grass can also be used as raw material for the production of bio-gas, bio-oil, charcoal (Strezov et al., 2008; Rocha et al., 2017), and alcohol (Shakil et al., 2013), as well as for the generation of electricity (Ohimain et al., 2014).

Elephant grass is known for high productive potential in tropical and subtropical regions; when properly managed, it can produce from 30 to $50 \mathrm{t} / \mathrm{ha} /$ year of dry matter (Pereira et al., 2016). In addition, elephant grass is resistant to drought, diseases and pests (Schmelzer, 1997).

However, one of the major limitations on the implantation and conduct of elephant grass fields is related to weed interference (Brighenti et al., 2017a). There is a lack of research on weed management in elephant grass, as most studies consider this species to be a weed rather than a crop (Cutts et al., 2011; Odero \& Gilbert, 2012; Grey et al., 2015).

Proper weed management during elephant grass implantation is very important, because the elephant grass crop is very sensitive in its early stages of growth (3-6 weeks after planting) (Brighenti et al., 2017b). Normally, elephant grass is installed during the rainy season in Brazil (November to January), which coincides with high temperatures, favoring the emergence and establishment of various weeds, especially grasses. These weeds, 
mainly Brachiaria species, demand special attention by growers at the moment of elephant grass crop implantation and conduction (Abreu et al., 2006).

Herbicides are the most commonly used method to control weeds. Carotenoid biosynthesis inhibitor herbicides, particularly those that inhibit the HPPD-enzyme, are noteworthy and commonly used on corn (Choe et al., 2014; Stephenson et al., 2015). HPPD-inhibiting herbicides have become popular among corn growers because of their broad-spectrum of weed control, flexible application timing, tank-mix compatibilities, and crop safety (Bollman et al., 2008; Walsh et al., 2012).

Another herbicide widely used on corn is atrazine (Rodrigues \& Almeida, 2011). It can be applied to a crop before, during or after planting of the seeds, or even after crop emergence. It is most often used at low rates in tank-mixes to improve broad-spectrum weed control (Bollman et al., 2008).

The development of methods for weed control by means of selective herbicides is an important practice in order to expand elephant grass cultivation in tropical and subtropical regions.

The objectives of this work were to evaluate the selectivity and weed control of HPPD-inhibiting herbicides alone or in combination with atrazine in elephant grass.

\section{Method}

\subsection{Study Sites}

Two experiments were conducted in experimental areas in the municipalities of Valença, Rio de Janeiro State, Brazil (22 $22^{\prime} 06.53^{\prime \prime} \mathrm{S}, 43^{\circ} 42^{\prime} 00.48^{\prime \prime} \mathrm{W}$; Experiment 1) and Coronel Pacheco, Minas Gerais State, Brazil (21 $33^{\circ} 11.10^{\prime \prime} \mathrm{S}, 43^{\circ} 15^{\prime} 56.32^{\prime \prime} \mathrm{W}$; Experiment 2).

\subsection{Experimental Implantations}

Experiment 1 was implanted under field conditions in a soil classified as Red-Yellow Argisol. The samples were collected at $0-20 \mathrm{~cm}$ depth and the results of the chemical and textural analyses were as follows: $\mathrm{pH}\left(\mathrm{H}_{2} \mathrm{O}\right)=5.1$, $\mathrm{P}=9.6 \mathrm{mg} \mathrm{dm}^{-3}, \mathrm{~K}=90 \mathrm{mg} \mathrm{dm}^{-3}, \mathrm{Ca}^{2+}=2.4 \mathrm{cmol}_{\mathrm{c}} \mathrm{dm}^{-3}, \mathrm{Mg}^{2+}=2.3 \mathrm{cmol}_{\mathrm{c}} \mathrm{dm}^{-3}, \mathrm{Al}^{3+}=0.0 \mathrm{cmol}_{\mathrm{c}} \mathrm{dm}^{-3}, \mathrm{H}+\mathrm{Al}=$ $3.3 \mathrm{cmol}_{\mathrm{c}} \mathrm{dm}^{-3}, \mathrm{SB}=4.93 \mathrm{cmol}_{\mathrm{c}} \mathrm{dm}^{-3}, \mathrm{CEC}(\mathrm{t})=4.93 \mathrm{cmol}_{\mathrm{c}} \mathrm{dm}^{-3}, \mathrm{CEC}\left(\mathrm{T}_{\mathrm{pH}=7.0}\right)=8.23 \mathrm{cmol}_{\mathrm{c}} \mathrm{dm}^{-3}, \mathrm{~V}=60 \%, \mathrm{C}$ organic $=1.94 \mathrm{dag} \mathrm{kg}^{-1}$, clay $=18 \%$, silt $=16 \%$, sand $=66 \%$.

Experiment 1 was installed on October 30, 2015. Before elephant grass planting, the experimental area was plowed and barred. Furrows $0.2 \mathrm{~m}$ deep, with spacing of $1.0 \mathrm{~m}$ between rows, were fertilized with $200 \mathrm{~kg}^{-1}$ of MAP (mono-ammonium phosphate). Stem cuttings of elephant grass cultivar 'BRS Capiaçu', $40 \mathrm{~cm}$ long with four buds per cutting, were planted in the furrows and covered with approximately $15 \mathrm{~cm}$ of soil. Each plot was four furrows (rows) wide by $5 \mathrm{~m}$ long $\left(20 \mathrm{~m}^{-2}\right.$ ). Plots were side-dressed with $40 \mathrm{~kg}$ of N ha ${ }^{-1}$ (urea) 30 days after planting.

The herbicide doses were applied on November 19, 2015, when the elephant grass plants were approximately $0.25 \mathrm{~m}$ tall. All herbicides were applied using a backpack sprayer (Herbicat Ltda, Catanduva, São Paulo State, Brazil), $\mathrm{CO}_{2}$ pressurized $\left(2 \mathrm{kgf} \mathrm{cm}^{-2}\right)$ to deliver a volume equivalent to $140 \mathrm{~L} \mathrm{ha}^{-1}$. The sprayer boom $(1.5 \mathrm{~m}$ length) comprised four flat fan nozzles (Magnojet BD 110 02), spaced $0.5 \mathrm{~m}$ apart. The environmental conditions during herbicide spraying were temperature, $27^{\circ} \mathrm{C}$; relative humidity, $68 \%$; and wind speed, $2 \mathrm{~m} \mathrm{~s}^{-1}$.

The predominant weed species and their densities at the time of herbicide applications were: Brachiaria plantaginea $\left(3.0\right.$ plants $\left.\mathrm{m}^{-2}\right)$, Ipomoea cordifolia $\left(2.0\right.$ plants $\left.\mathrm{m}^{-2}\right)$, Cyperus esculentus $\left(4.0\right.$ plants $\left.\mathrm{m}^{-2}\right)$ and Commelina benghalensis (3.0 plants $\left.\mathrm{m}^{-2}\right)$.

Experiment 2 was installed on May 25, 2017, in Coronel Pacheco. Containers of $5 \mathrm{~kg}$ capacity were filled with a substrate containing equal quantities of sand, manure and soil. Three elephant grass (cultivar 'BRS Capiaçu') stem cuttings (10 cm long) were planted in containers arranged on benches and directly exposed to the sun (under field conditions). Weekly irrigations were performed in order to maintain the substrate in the field capacity. After emergence, two plants were kept per container.

The treatments were applied on June 22, 2017, using the same sprayer and calibration mentioned above. The environmental conditions during the herbicide spraying were temperature, $22{ }^{\circ} \mathrm{C}$; relative humidity, $66 \%$; and wind speed, $3 \mathrm{~m} \mathrm{~s}^{-1}$. At that time, plants were $0.25 \mathrm{~m}$ tall on average.

\subsection{Treatments and Experimental Designs}

A completely randomized block design with four replicates was used in Experiment 1. The treatments applied were as follows: two rates of mesotrione $\left(0.072\right.$ and $0.144 \mathrm{~kg} \mathrm{ha}^{-1}+0.5 \% \mathrm{v} / \mathrm{v}$ mineral oil - Assist () ), two rates of tembotrione $\left(0.075\right.$ and $0.100 \mathrm{~kg} \mathrm{ha}^{-1}+0.5 \% \mathrm{v} / \mathrm{v}$ mineral oil - Aureo $\left.\AA\right)$, atrazine plus mesotrione $(1.25+0.072$ 
$\mathrm{kg} \mathrm{ha}^{-1}+0.5 \% \mathrm{v} / \mathrm{v}$ mineral oil - Assist $\left.{ }^{\circledR}\right)$, atrazine plus tembotrione $\left(1.25+0.100 \mathrm{~kg} \mathrm{ha}^{-1}+0.5 \% \mathrm{v} / \mathrm{v}\right.$ mineral oil - Aureo $\left.{ }^{\circledR}\right)$, atrazine plus mesotrione $\left(1.25+0.072 \mathrm{~kg} \mathrm{ha}^{-1}\right)$, atrazine plus tembotrione $\left(1.25+0.100 \mathrm{~kg} \mathrm{ha}^{-1}\right)$ and two checks [weed-free check (manual weed control) and weedy check (without manual weed control)]. Experiment 2 was arranged in a completely randomized design with four replications. The same herbicidal treatments of Experiment 1 were applied, plus a check without herbicide application.

\subsection{Measurements of Elephant Grass and Weeds}

Phytotoxic effects of herbicide treatments on the elephant grass and the weed control were evaluated on a scale of $0 \%$ to $100 \%$ at 10, 20 and 30 days after treatments (DAT). The value zero corresponded to no symptoms of phytotoxicity on elephant grass plants or no weed control, and $100 \%$ to complete elephant grass death or complete weed control (SBCPD, 1995).

All weed species were cut on the soil surface within a quadrat $(0.5 \times 0.5 \mathrm{~m})$ to determine aboveground fresh matter weight at 30 DAT.

For both experiments, green color indices were evaluated on elephant grass leaves at 23 DAT using a SPAD-502 chlorophyll meter (Konica Minolta, Japan). Simultaneously with the SPAD index evaluation, the elephant grass plant height was determined in Experiment 2 using a graduated ruler.

The harvest and determination of forage yield were performed on February 15, 2016, approximately 110 days after elephant grass establishment (Experiment 1). Plants were cut within a quadrat $(1.0 \times 1.0 \mathrm{~m})$ at the soil surface to quantify the aboveground biomass. Harvested plants were weighed, placed in a forced-air ventilation oven at $65{ }^{\circ} \mathrm{C}$ for $72 \mathrm{~h}$; and subsequently reweighed. The values of fresh and dry matter weight of elephant grass were converted to $\mathrm{kg} \mathrm{ha}^{-1}$.

In Experiment 2, the harvest was carried out on July 13, 2017. The plants were cut at the soil surface in order to obtain the aboveground biomass per container. The plants were placed in paper bags and dried using the same procedure described in Experiment 1. The dried matter weights were then recorded.

\subsection{Statistical Analysis}

The percentage of phytotoxicity for both experiments and the weed control percentages of Experiment 1 were normalized by square root transformation of $(\mathrm{x}+1)$ to perform analysis of variance tests. Data were subjected to analyses of variance, and the mean values were compared using the Scott-Knott test $(P \leq 0.05)$. Statistical analyses were performed using SAEG software (Ribeiro Júnior, 2001).

\subsection{Climate Conditions}

The mean monthly air temperatures (mean, maximum and minimum) and rainfall during the experimental periods are shown in Table 1.

Table 1. Average maximum and minimum monthly air temperatures (T), and rainfall during experiments conducted at Valença, Rio de Janeiro State, and Coronel Pacheco, Minas Gerais State, Brazil

\begin{tabular}{|c|c|c|c|c|c|c|c|c|}
\hline \multirow{2}{*}{$\begin{array}{l}\text { Municipality } \\
\text { Month/Year }\end{array}$} & \multicolumn{5}{|c|}{ Valença } & \multicolumn{3}{|c|}{ Caronel Pacheco } \\
\hline & Oct/15 & Nov/15 & Dec/15 & $\mathrm{Jan} / 16$ & Fev/16 & May/17 & Jun/17 & $\mathrm{Jul} / 17$ \\
\hline Maximum $\mathrm{T}\left({ }^{\circ} \mathrm{C}\right)$ & 29.2 & 29.9 & 31.6 & 29.9 & 32.6 & 22.2 & 21.7 & 20.0 \\
\hline Minimum $\mathrm{T}\left({ }^{\circ} \mathrm{C}\right)$ & 20.8 & 20.7 & 20.7 & 20.5 & 20.7 & 21.0 & 20.2 & 18.5 \\
\hline Rainfall (mm) & 75.3 & 118.8 & 141.4 & 388.2 & 222.4 & 68.4 & 23.6 & 7.0 \\
\hline
\end{tabular}

\section{Results and Discussion}

The application of two rates of mesotrione with the addition of mineral oil or the tank mixture of atrazine plus mesotrione, with or without the addition of mineral oil, were highly selective to elephant grass plants (Tables 2 and 3). In both experiments, those treatments presented $0 \%$ phytotoxicity, at 30 DAT.

The response of millet (Cultivar 'ADR-300'), submitted to the dose of $60 \mathrm{~g} \mathrm{ha}^{-1}$ of mesotrione, was evaluated by Dias et al. (2015). The results also indicated selectivity of this herbicide to millet, since there was no damage to plant growth. Other studies conducted by Abit et al. (2009) revealed the possibility of using mesotrione in sorghum. Several genotypes were submitted to post-emergence applications at doses of $0,52,105,210$ and $315 \mathrm{~g}$ $\mathrm{ha}^{-1}$. The results showed 17 mesotrione-tolerant sorghum hybrids, and, when grown under field conditions, the symptoms of injury did not correlate with crop yield. Takano et al. (2016) evaluated mesotrione (50 and $100 \mathrm{~g}$ 
$\left.\mathrm{ha}^{-1}\right)$ and the mixture of atrazine plus mesotrione $\left(1000+50 \mathrm{~g} \mathrm{ha}^{-1}\right)$ in six sorghum hybrids. These treatments were selective for the sorghum crop, demonstrating that they were an option for post-emergence application.

The two doses of tembotrione with the addition of mineral oil caused total death of the plants, already in the second evaluation, at 20 DAT (Experiment 1, Table 2). These values were also high and varied from $87 \%$ to $94 \%$ at 30 DAT in Experiment 2 (Table 3).

Table 2. Percentage of phytotoxicity on elephant grass plants at 10, 20 and 30 days after application of the treatments. Valença. Rio de Janeiro State, Brazil. (Experiment 1)

\begin{tabular}{|c|c|c|c|c|}
\hline \multirow{2}{*}{ Treatments } & \multirow{2}{*}{ Doses $\left(\mathrm{kg} \mathrm{ha}^{-1}\right)$} & \multicolumn{3}{|c|}{ Days after treatment } \\
\hline & & 10 & 20 & 30 \\
\hline Mesotrione & $0.072+0.5 \%$ oil & $0.0 \mathrm{D}^{1}$ & $0.0 \mathrm{D}$ & $0.0 \mathrm{C}$ \\
\hline Mesotrione & $0.144+0.5 \%$ oil & $0.0 \mathrm{D}$ & $0.0 \mathrm{D}$ & $0.0 \mathrm{C}$ \\
\hline Tembotrione & $0.075+0.5 \%$ oil & $98.0 \mathrm{~A}$ & $100.0 \mathrm{~A}$ & $100.0 \mathrm{~A}$ \\
\hline Tembotrione & $0.100+0.5 \%$ oil & $98.2 \mathrm{~A}$ & $100.0 \mathrm{~A}$ & $100.0 \mathrm{~A}$ \\
\hline Atrazine + Mesotrione & $1.25+0.072+0.5 \%$ oil & $0.0 \mathrm{D}$ & $0.0 \mathrm{D}$ & $0.0 \mathrm{C}$ \\
\hline Atrazine + Tembotrione & $1.25+0.100+0.5 \%$ oil & $87.7 \mathrm{~B}$ & $98.0 \mathrm{~B}$ & $100.0 \mathrm{~A}$ \\
\hline Atrazine + Mesotrione & $1.25+0.072$ & $0.0 \mathrm{D}$ & $0.0 \mathrm{D}$ & $0.0 \mathrm{C}$ \\
\hline Atrazine + Tembotrione & $1.25+0.100$ & $14.7 \mathrm{C}$ & $54.2 \mathrm{C}$ & $65.0 \mathrm{~B}$ \\
\hline Weed-free Check & - & $0.0 \mathrm{D}$ & $0.0 \mathrm{D}$ & $0.0 \mathrm{C}$ \\
\hline Weedy Check & - & $0.0 \mathrm{D}$ & $0.0 \mathrm{D}$ & $0.0 \mathrm{C}$ \\
\hline Coeficient of Variation $(\%)$ & - & 1.2 & 0.8 & 0.3 \\
\hline
\end{tabular}

Note. ${ }^{1}$ Mean values followed by different letters are significantly different $(P \leq 0.05)$ by Scott-Knott.

Table 3. Percentage of phytotoxicity on elephant grass plants at 10, 20 and 30 days after application of the treatments. Coronel Pacheco. Minas Gerais State. Brazil. (Experiment 2)

\begin{tabular}{|c|c|c|c|c|}
\hline \multirow{2}{*}{ Treatments } & \multirow{2}{*}{ Doses $\left(\mathrm{kg} \mathrm{ha}^{-1}\right)$} & \multicolumn{3}{|c|}{ Days after treatment } \\
\hline & & 10 & 20 & 30 \\
\hline Mesotrione & $0.072+0.5 \%$ oil & $0.0 \mathrm{H}^{1}$ & $0.0 \mathrm{E}$ & $0.0 \mathrm{E}$ \\
\hline Mesotrione & $0.144+0.5 \%$ oil & $1.6 \mathrm{~F}$ & $0.6 \mathrm{E}$ & $0.0 \mathrm{E}$ \\
\hline Tembotrione & $0.075+0.5 \%$ oil & $40.6 \mathrm{C}$ & $80.3 \mathrm{C}$ & $87.3 \mathrm{C}$ \\
\hline Tembotrione & $0.100+0.5 \%$ oil & $70.3 \mathrm{~B}$ & $85.6 \mathrm{~B}$ & $94.0 \mathrm{~B}$ \\
\hline Atrazine + Mesotrione & $1.25+0.072+0.5 \%$ oil & $5.6 \mathrm{E}$ & $2.6 \mathrm{E}$ & $0.0 \mathrm{E}$ \\
\hline Atrazine + Tembotrione & $1.25+0.100+0.5 \%$ oil & $83.0 \mathrm{~A}$ & $91.6 \mathrm{~A}$ & $100.0 \mathrm{~A}$ \\
\hline Atrazine + Mesotrione & $1.25+0.072$ & $0.6 \mathrm{G}$ & $0.3 \mathrm{E}$ & $0.0 \mathrm{E}$ \\
\hline Atrazine + Tembotrione & $1.25+0.100$ & $12.3 \mathrm{D}$ & $58.3 \mathrm{D}$ & $61.6 \mathrm{D}$ \\
\hline Check & - & $0.0 \mathrm{H}$ & $0.0 \mathrm{E}$ & $0.0 \mathrm{E}$ \\
\hline Coeficient of Variation (\%) & - & 2.9 & 3.1 & 0.9 \\
\hline
\end{tabular}

Note. ${ }^{1}$ Mean values followed by different letters are significantly different $(P \leq 0.05)$ by Scott-Knott test.

Characteristic symptoms were the appearance of bleached leaves and stunted plants. Herbicides of this chemical group inhibit the enzyme 4-hydroxyphenylpyruvate dioxygenase (HPPD), acting in the conversion of tyrosine to plastoquinone and $\alpha$-tocopherol. The inhibition of plastoquinone leads to an interruption of the carotenoid synthesis pathway (Oliveira Júnior, 2011). The blocking synthesis of these pigments is responsible for the characteristic symptom of depigmentation or "albinism" due to the lack of chlorophyll protection from photodegradation. Growth ceases in absence of the production of green photosynthetic pigments and symptoms of necrosis and plant death begin to appear. Tembotrione $\left(100.8 \mathrm{~g} \mathrm{ha}^{-1}\right)$ was applied alone and in a tank mix with atrazine $\left(1,500 \mathrm{~g} \mathrm{~h}^{-1}\right)$ on three sorghum cultivars (Galon et al., 2016). These treatments were highly detrimental to cultivars, with percentages of phytotoxicity varying from $98 \%$ to $100 \%$.

Atrazine and tembotrione in a tank-mix plus mineral oil provided high levels of phytotoxicity and plant death at 30 DAT (100\%) (Tables 2 and 3). Reductions in the percentage of phytotoxicity were observed for atrazine plus 
tembotrione without mineral oil, ranging from $12 \%$ to $65 \%$ in both experiments. However, these values were still high and resulted in significant forage yield loss (Tables 4 and 5).

Table 4. SPAD indices (SPAD) on elephant grass plants, fresh matter weight (FMW) (kg ha $\left.{ }^{-1}\right)$ and dry matter weight (DMW) $\left(\mathrm{kg} \mathrm{ha}^{-1}\right)$ of elephant grass. Valença, Rio de Janeiro State, Brazil. (Experiment 1)

\begin{tabular}{lllll}
\hline Treatments & Doses $\left(\mathrm{kg} \mathrm{ha}^{-1}\right)$ & SPAD & FMW & DMW \\
\hline Mesotrione & $0.072+0.5 \%$ oil & $56.3 \mathrm{~A}^{1}$ & $159.300 .0 \mathrm{~A}$ & $44.720 .19 \mathrm{~A}$ \\
Mesotrione & $0.144+0.5 \%$ oil & $56.2 \mathrm{~A}$ & $177.125 .0 \mathrm{~A}$ & $43.239 .14 \mathrm{~A}$ \\
Tembotrione & $0.075+0.5 \%$ oil & $18.4 \mathrm{D}$ & $53.800 .0 \mathrm{C}$ & $14.598 .98 \mathrm{C}$ \\
Tembotrione & $0.100+0.5 \%$ oil & $30.4 \mathrm{C}$ & $64.850 .00 \mathrm{C}$ & $17.496 .23 \mathrm{C}$ \\
Atrazine + Mesotrione & $1.25+0.144+0.5 \%$ oil & $53.3 \mathrm{~A}$ & $165.750 .0 \mathrm{~A}$ & $46.533 .98 \mathrm{~A}$ \\
Atrazine + Tembotrione & $1.25+0.100+0.5 \%$ oil & $30.9 \mathrm{C}$ & $79.400 .0 \mathrm{C}$ & $21.460 .32 \mathrm{C}$ \\
Atrazine + Mesotrione & $1.25+0.144$ & $53.9 \mathrm{~A}$ & $180.050 .0 \mathrm{~A}$ & $49.079 .70 \mathrm{~A}$ \\
Atrazine + Tembotrione & $1.25+0.100$ & $46.7 \mathrm{~B}$ & $119.600 .0 \mathrm{~B}$ & $34.635 .12 \mathrm{~B}$ \\
Weed-free Check & - & $53.4 \mathrm{~A}$ & $163.600 .0 \mathrm{~A}$ & $44.557 .86 \mathrm{~A}$ \\
Weedy Check & - & $50.1 \mathrm{~B}$ & $69.600 .0 \mathrm{C}$ & $19.920 .53 \mathrm{C}$ \\
Coeficient of Variation $(\%)$ & - & 7.1 & 12.8 & 17.9 \\
\hline
\end{tabular}

Note. ${ }^{1}$ Mean values followed by different letters are significantly different $(P \leq 0.05)$ by Scott-Knott test.

Table 5. SPAD indices (SPAD), plant height $(\mathrm{H})(\mathrm{cm})$, fresh (FMW) and dry matter weight (DMW) $\left(\mathrm{g} \mathrm{container}{ }^{-1}\right)$ of elephant grass. Coronel Pacheco, Minas Gerais State, Brazil. (Experiment 2)

\begin{tabular}{llllll}
\hline Treatments & Doses $\left(\mathrm{kg} \mathrm{ha}^{-1}\right)$ & SPAD & H & FMW & DMW \\
\hline Mesotrione & $0.072+0.5 \%$ oil & $28.5 \mathrm{~A}^{1}$ & $60.1 \mathrm{~A}$ & $98.5 \mathrm{~A}$ & $22.7 \mathrm{~A}$ \\
Mesotrione & $0.144+0.5 \%$ oil & $28.9 \mathrm{~A}$ & $58.7 \mathrm{~A}$ & $109.4 \mathrm{~A}$ & $23.9 \mathrm{~A}$ \\
Tembotrione & $0.075+0.5 \%$ oil & $13.0 \mathrm{~B}$ & $43.3 \mathrm{~B}$ & $53.3 \mathrm{~B}$ & $17.3 \mathrm{~B}$ \\
Tembotrione & $0.100+0.5 \%$ oil & $11.4 \mathrm{~B}$ & $40.0 \mathrm{~B}$ & $36.6 \mathrm{~B}$ & $15.6 \mathrm{~B}$ \\
Atrazine + Mesotrione & $1.25+0.072+0.5 \%$ oil & $27.8 \mathrm{~A}$ & $56.6 \mathrm{~A}$ & $97.3 \mathrm{~A}$ & $22.2 \mathrm{~A}$ \\
Atrazine + Tembotrione & $1.25+0.100+0.5 \%$ oil & $0.0 \mathrm{C}$ & $0.0 \mathrm{C}$ & $17.3 \mathrm{C}$ & $14.9 \mathrm{~B}$ \\
Atrazine + Mesotrione & $1.25+0.072$ & $28.1 \mathrm{~A}$ & $56.6 \mathrm{~A}$ & $96.6 \mathrm{~A}$ & $22.5 \mathrm{~A}$ \\
Atrazine + Tembotrione & $1.25+0.100$ & $13.0 \mathrm{~B}$ & $36.6 \mathrm{~B}$ & $42.5 \mathrm{~B}$ & $16.9 \mathrm{~B}$ \\
Check & - & $28.6 \mathrm{~A}$ & $56.7 \mathrm{~A}$ & $106.0 \mathrm{~A}$ & $24.0 \mathrm{~A}$ \\
\hline Coeficient of Variation $(\%)$ & - & 5.5 & 7.2 & 12.7 & 5.9 \\
\hline
\end{tabular}

Note. ${ }^{1}$ Mean values followed by different letters are significantly different $(P \leq 0.05)$ by Scott-Knott test.

All treatments of mesotrione plus mineral oil or a tank mixture of atrazine plus mesotrione, with or without the addition of mineral oil, resulted in SPAD index values statistically equal to the weed-free check (Experiment 1) and the check without application (Experiment 2) (Tables 4 and 5, respectively). This result was also verified for elephant grass plant height in Experiment 2 (Table 5). Mesotrione plus mineral oil or a tank mixture of atrazine plus mesotrione, with or without the addition of mineral oil did not reflecte in forage yield losses, where values of fresh and dry matter weights were similar to those reached in the weed-free check and in the check without application (Tables 4 and 5, respectively).

On the other hand, treatments with tembotrione plus mineral oil and atrazine plus tembotrione with and without mineral oil resulted in low SPAD index values (Tables 4 and 5). This fact reinforced the results obtained with visual evaluations of phytotoxicity. Elephant grass growth and development, which were adversely affected which reflected in forage yield losses.

Even though tembotrione has been registered for corn in post-emergence applications (Rodrigues \& Almeida 2011; Idziak \& Woznica, 2014), some sweet corn genotypes are sensitive to it (Bollman et al., 2008). The corn hybrid 'Merit' cultivar presents low tolerance to tembotrione applied alone or in a tank mixture with atrazine.

Weed interference in elephant grass can be measured when comparing the two checks (Table 4). The reduction of elephant grass fresh and dry matter weights was evident as a result of weed interference. The weedy check 
yielded $42.5 \%$ and $44.7 \%$ significantly less fresh and dry matter weights when compared to the weed-free check, respectively.

Weed control in all mesotrione treatments ranged from $77 \%$ to $87 \%$ at 30 DAT (Table 6).

Table 6. Percentage of weed control on elephant grass plants at 10,20 and 30 days after application of the

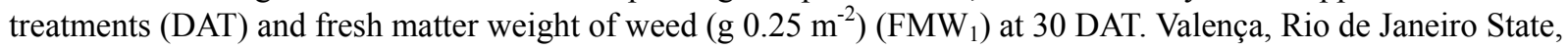
Brazil. (Experiment 1)*

\begin{tabular}{llllll}
\hline \multirow{2}{*}{ Treatments } & Doses $\left(\mathrm{kg} \mathrm{ha}^{-1}\right)$ & \multicolumn{4}{c}{ Days after treatment } \\
\cline { 3 - 5 } & & 10 & 20 & 30 & $\mathrm{FMW}_{1}$ \\
\hline Mesotrione & $0.072+0.5 \%$ oil & $62.5 \mathrm{D}^{1}$ & $50.0 \mathrm{E}$ & $77.2 \mathrm{E}$ & $1.47 \mathrm{~B}$ \\
Mesotrione & $0.144+0.5 \%$ oil & $78.2 \mathrm{C}$ & $62.5 \mathrm{C}$ & $87.2 \mathrm{C}$ & $0.90 \mathrm{~B}$ \\
Tembotrione & $0.075+0.5 \%$ oil & $98.7 \mathrm{~A}$ & $99.5 \mathrm{~A}$ & $100.0 \mathrm{~A}$ & $0.62 \mathrm{~B}$ \\
Tembotrione & $0.100+0.5 \%$ oil & $99.5 \mathrm{~A}$ & $100.0 \mathrm{~A}$ & $100.0 \mathrm{~A}$ & $1.04 \mathrm{~B}$ \\
Atrazine + Mesotrione & $1.25+0.072+0.5 \%$ oil & $57.2 \mathrm{E}$ & $50.2 \mathrm{E}$ & $85.0 \mathrm{D}$ & $1.01 \mathrm{~B}$ \\
Atrazine + Tembotrione & $1.25+0.100+0.5 \%$ oil & $99.5 \mathrm{~A}$ & $100.0 \mathrm{~A}$ & $100.0 \mathrm{~A}$ & $0.61 \mathrm{~B}$ \\
Atrazine + Mesotrione & $1.25+0.072$ & $60.7 \mathrm{D}$ & $58.2 \mathrm{D}$ & $84.7 \mathrm{D}$ & $0.98 \mathrm{~B}$ \\
Atrazine + Tembotrione & $1.25+0.100$ & $87.2 \mathrm{~B}$ & $89.2 \mathrm{~B}$ & $95.5 \mathrm{~B}$ & $0.96 \mathrm{~B}$ \\
Weed-free Check & - & $100.0 \mathrm{~A}$ & $100.0 \mathrm{~A}$ & $100.0 \mathrm{~A}$ & $0.26 \mathrm{~B}$ \\
Weedy Check & - & $0.0 \mathrm{~F}$ & $0.0 \mathrm{~F}$ & $0.0 \mathrm{~F}$ & $2.44 \mathrm{~A}$ \\
Coeficient of Variation $(\%)$ & - & 1.8 & 0.9 & 0.5 & 54.2 \\
\hline
\end{tabular}

Note.* Weed species were as follows: Brachiaria plantaginea, Ipomoea cordifolia, Cyperus esculentus and Commelina benghalensis. ${ }^{1}$ Mean values followed by different letters are significantly different $(P \leq 0.05)$ by Scott-Knott test.

Although the lowest dose of this herbicide resulted in $77 \%$ weed control, there was no loss on forage yield in function of weed interference. The addition of atrazine to mesotrione provided improvements in weed control. The percentage of weed control, at 30 DAT, ranged from $77 \%$ (mesotrione: $0.072+0.5 \%$ oil) to $85 \%$ (atrazine + mesotrione: $1.25+0.072+0.5 \%$ oil). Williams et al. (2011) emphasized the importance of using atrazine in a tank-mix with other herbicides due to the increase in spectrum of weed control. The authors observed that in tank mixing of atrazine with HPPD-inhibiting herbicides provided increases in the number and weight of ears of sweet corn of $9 \%$ and $13 \%$, respectively, when compared to these herbicides applied alone.

The best weed control treatments were tembotrione alone or in combination with atrazine; the percentages ranged from $95 \%$ to $100 \%$, at 30 DAT. All herbicide treatments reduced the fresh matter weights of weeds, differing statistically from the weedy check.

\section{Conclusions}

This research provides alternatives to weed control in elephant grass fields. Different herbicide options that are feasible for use in elephant grass can facilitate increases in cultivated areas and forage supplies, mainly in tropical and subtropical regions.

Two application rates of mesotrione with the addition of mineral oil or the tank mixture of atrazine plus mesotrione, with or without the addition of mineral oil, did not provide injuries capable to reduce elephant grass forage yield. Tembotrione was phytotoxic to elephant grass when applied with mineral oil. Atrazine plus tembotrione in a tank-mix, with or without mineral oil, were also phytotoxic to elephant grass. All treatments provided satisfactory weed control.

\section{Acknowledgements}

We are grateful to Fundação de Amparo a Pesquisa do Estado de Minas Gerais (FAPEMIG) and the Conselho Nacional de Desenvolvimento Científico e Tecnológico (CNPq) for cooperation during the study.

\section{References}

Abit, M. J. M., Al-Khatib, K., Regehr, D. L., Tuinstra, M. R., Claassen, M. M., Geier, P. W., ... Currie, R. S. (2009). Differential response of grain sorghum hybrids to foliar-applied mesotrione. Weed Technology, 23(1), 28-33. https://doi.org/10.1614/WT-08-086.1 
Abreu, J. G., Evangelista, A. R., Souza, I. F., Rocha, G. P., Soares, L. Q., \& Santarosa, L. C. (2006). Glyphosate e nitrogênio no controle de Brachiaria decumbens STAPF em capineiras estabelecidas. Ciência e Agrotecnologia, 30(5), 977-987. http://dx.doi.org/10.1590/S1413-70542006000500023

Bollman, J. D., Boerboom, C. M., Becker, R. L., \& Fritz, V. A. (2008). Efficacy and tolerance to HPPD-inhibiting herbicides in sweet corn. Weed Technology, 22(4), 666-674. https://doi.org/10.1614/ WT-08-036.1

Brighenti, A. M., Calsavara, L. H. F., \& Varotto, Y. V. G. (2017a). Preemergence herbicides on weed control in elephant grass pasture. Ciência e Agrotecnologia, 41(1), 52-59. https://doi.org/10.1590/1413-70542 017411024516

Brighenti, A. M., Ledo, F. J. S., Machado, J. C., Calsavara, L. H. F., \& Varotto, Y. V. G. (2017b). Elephant grass response to amino-acid synthesis inhibitor herbicides. Australian Journal of Crop Science, 11(1), 38-42. https://doi.org/10.21475/ajcs.2017.11.01.pne187

Choe, E., Williams, M. M., Boydston, R. A., Huber, J. L., Huber, S. C., \& Pataky, J. K. (2014). Photosystem II-Inhibitors play a limited role in sweet corn response 4-hydroxyphenyl pyruvate dioxygenase-Inhibiting herbicides. Agronomy Journal, 106(4), 1317-1323. https://doi.org/10.2134/agronj13.0570

Cutts, G. S., Webster, T. M., Grey, T. L., Vencill, W. K., Lee, R. D., ... Anderson, W. F. (2011). Herbicide effect on napier grass (Pennisetum purpureum) control. Weed Science, 59, 255-262. https://doi.org/10.1614/ WS-D-10-00130.1

Dias, R. C., Gonçalves, C. G., Reis, M. R., Mendes, K. F., Carneiro, G. D. O. P., Melo, C. A. D., \& Pereira, A. A. (2015). Seletividade de herbicidas aplicados em pós-emergência no milheto. Revista Brasileira de Herbicidas, 14(4), 348-355. https://doi.org/10.7824/rbh.v14i4.455

Galon, L., Fernandes, F. F., Andres, A., Silva, A. F., \& Forte, C. T. (2016). Selectivity and efficiency of herbicides in weed control on sweet sorghum. Pesquisa Agropecuária Tropical, 46(2), 123-131. https://doi.org/10.1590/1983-40632016v4639431

Grey, T. L., Webster, T. M., Li, X., Anderson, W., \& Cutts, G. S. (2015). Evaluation of control of napier grass (Pennisetum purpureum) with tillage and herbicides. Invasive Plant Science \& Management, 8(4), 393-400. https://doi.org/10.1614/IPSM-D-15-00012.1

Idziak, R., \& Woznica, Z. (2014). Impact of tembotrione and flufenacet plus isoxaflutole application timings, rates and adjuvant type on weeds and yield of maize. Chilean Journal of Agricultural Research, 72(2), 129-134. https://doi.org/10.4067/S0718-58392014000200001

Maia, I. S. A. S., Braga, A. P., Gerra, D. G. F., \& Lima Júnior, D. M. (2015). Valor nutritivo de silagens de capim elefante com níveis crescentes de resíduo da agroindústria da acerola. Acta Veterinária Brasílica, 9(2), 190-194.

Odero, D. C., \& Gilbert, R. A. (2012). Dose-response of newly establish (Pennisetum purpureum) to postemergence herbicides. Weed Technology, 26(4), 691-698. https://doi.org/10.1614/WT-D-12-00039.1

Ohimain, E. I., Kendabie, P., \& Nwachukwu, R. E. S. (2014). Bioenergy potentials of elephant grass. Pennisetum purpureum Schumach. Annual Research \& Review in Biology, 4(13), 2215-2227. https://doi.org/10.9734/ARRB/2014/8722

Oliveira Júnior, R. S. (2011). Mecanismos de ação de herbicidas. In R. S. Oliveira Júnior, J. Constantin, \& M. H. Inoue (Eds.), Biologia e manejo de plantas daninhas (pp. 141-191). Omnipax, Curitiba, Brasil.

Pereira, A. V., Ledo, F. J. S., Morenz, M. J. F., Leite, J. L. B., Brighenti, A. M., Martins, C. E., \& Machado, J. C. (2016). BRS Capiaçu: Cultivar de capim-elefante de alto rendimento para produção de silagem. Comunicado Técnico 79, Embrapa Gado de Leite, Juiz de Fora, Brazil.

Ribeiro Júnior, J. I. (2001). Análises estatísticas no SAEG. Editora UFV, Viçosa, Brazil.

Rocha, J. R. A. S. C., Machado, J. C., Carneiro, P. C. S., Carneiro, J. C., Resende, M. D. V., Ledo, F. J. S., \& Carneiro, J. E. S. (2017). Bioenergetic potential and genetic diversity of elephantgrass via morpho-agronomic and biomass quality traits. Industrial Crops and Products, 95, 485-492. https://doi.org/10.1016/j.incrop.2016.10.060

Rodrigues, B. N., \& Almeida, F. S. (2011). Guia de herbicidas. Grafmarke, Londrina, Brazil. 
Santos, R. J. C., Lira, M. A., Guim, A., Santos, M. V. F., Dubeux Júnior, J. C. B., \& Mello, A. C. L. (2013). Elephant grass clones for silage production. Scientia Agricola, 70(1), 6-11. https://doi.org/10.1590/ S0103-90162013000100002

SBCPD. (1995). Procedimentos para instalação e análise de experimentos com herbicidas. Sociedade Brasileira da Ciência das Plantas Daninhas. Londrina, Brazil.

Schmelzer, G. H. (1997). Review of Pennisetum section Brevivalvula (Poaceae). Euphytica, 97(1), 1-20. https://doi.org/10.1023/A:1003077906928

Shakil, S. R., Hoque, M. A., Rouf, N. T., Chakraborty, P., \& Hossain, M. S. (2013). Extraction of bio-fuel from a second generation energy crop (Pennisetum purpureum K. Schumach) and its future prospects in Bangladesh. International Journal of Environmental Science and Development, 4(6), 668-671. https://doi.org/10.7763/IJESD.2013.V4.435

Stephenson, D. O., Bond, J. A., Landry, R. L., \& Edwards, H. M. (2015). Weed management in corn with postemergence applications of tembotrione or thiencarbazone: tembotrione. Weed Technology, 29(3), 350-358. https://doi.org/10.1614/WT-D-14-00104.1

Strezov, V., Evans, T. J., \& Hayman, C. (2008). Thermal conversion of elephant grass (Pennisetum purpureum Schum) to bio-gas, bio-oil and charcoal. Bioresource Technology, 99(17), 8394-8399. https://doi.org/ 10.1016/j.biortech.2008.02.039

Takano, H. K., Rubin, R. S., Marques, L. H., Tronquini, S. M., Fadin, D. A., Kalsing, A., ... Pupim Junior, O. (2016). Potential use of herbicides in different sorghum hybrids. African Journal of Agricultural Research, 11(26), 2277-2285. https://doi.org/10.5897/AJAR2016.11190

Walsh, M. J., Stratford, K., Stone, K., \& Powles, S. B. (2012). Synergistic effects of atrazine and mesotrione on susceptible and resistant wild rasish (Raphanus raphanistrum) population and the potential for overcoming resistance to triazine herbicides. Weed Technology, 26(2), 341-347. https://doi.org/10.1614/WT-D-1100132.1

Williams, M. M., Boydston, R. A., Peachey, R. E., \& Robinson, D. (2011). Significance of atrazine as a tank-mix partner with tembotrione. Weed Technology, 25(3), 299-302. https://doi.org/10.1614/WT-D-10-00140.1

\section{Copyrights}

Copyright for this article is retained by the author(s), with first publication rights granted to the journal.

This is an open-access article distributed under the terms and conditions of the Creative Commons Attribution license (http://creativecommons.org/licenses/by/4.0/). 